\title{
Support of Dinuclear Copper Triketonate Complexes on Silica: Monolayer Loading from Complex Footprint and the First Crystallographically Characterized cis Dipyridine Adduct
}

Samantha A. Ranaweera ${ }^{a}$, Mathew D. Rowe ${ }^{b}$, Keisha B. Walters ${ }^{b}$, William P. Henry ${ }^{a}$, Mark G. White ${ }^{\mathrm{b} *}$, Jose M. Rodriguez ${ }^{\mathrm{c}^{*}}$

${ }^{a}$ Department of Chemistry, Mississippi State University, Mississippi State, MS 39762, USA

${ }^{b}$ Dave C. Swalm School of Chemical Engineering, Mississippi State University, Mississippi State, MS 39762, USA

${ }^{\mathrm{C}}$ Mississippi State Chemical Laboratory, Mississippi State University, Mississippi State, MS 39762, USA

*Corresponding authors at: (J.M.Rodriguez) Mississippi State Chemical Laboratory, Mississippi State University. Tel.: +1 6623252653; fax: +1 6623257807. E-mail: jmr385@msstate.edu and (M. G.White) white@che.msstate.edu

\section{ABSTRACT}

To demonstrate that monolayer coverage of a complex can be estimated from the footprint area of the complex and surface area of the support, various loadings of two dinuclear copper complexes, bis(heptane-2,4,6-trionato)dicopper(II) [ $\left.\mathrm{Cu}_{2}(\mathrm{daa})_{2}\right]$ and bis(1,5-diphenyl-1,3,5pentanetrionato)dicopper(II) $\left[\mathrm{Cu}_{2}(\mathrm{dba})_{2}\right]$, were supported on Cab-O-Sil by batch impregnation. The supported samples were characterized by elemental analysis, powder XRD, DRIFTS, EPR spectroscopy, and TGA. Elemental analysis and TGA data confirm that the $\mathrm{Cu}_{2}(\text { daa })_{2}$ complex loses one triketonate ligand upon adsorption onto silica from THF solution and therefore is not suitable for estimating monolayer coverage. By contrast, the $\mathrm{Cu}_{2}(\mathrm{dba})_{2}$ complex was adsorbed on the silica surface intact from $\mathrm{CH}_{2} \mathrm{Cl}_{2}$. PXRD and DRIFTS confirmed the partial loading of the second $\mathrm{Cu}_{2}(\mathrm{dba})_{2}$ layer on the Cab-O-Sil surface for samples containing $\geq 2.64 \mathrm{wt} \%$ copper. This agrees with a predicted loading based on the surface area of the support and footprint of the complex which was determined by X-ray crystallography of the dipyridine adduct. This is the first dicopper bis triketonate complex in which the pyridines are cis.

Keywords: Batch impregnation; Bis(heptane-2,4,6-trionato)dicopper(II); Bis(1,5-diphenyl-1,3,5pentanetrionato)dicopper(II); Silica supported; Triketonate complexes; Dicopper

\section{Introduction}

The deposition of metal complexes onto solid supports is an important process in many emerging technologies. For example, supported metal complexes have potential use in 
nanotechnology,[1, 2] electronic materials,[3] light harvesting,[4] and catalyst preparation.[5-7] As such, there is a need for an understanding of the deposition processes that occur and the ability to predict the amount of complex necessary to form a monolayer as the reactivity and properties of the complex-supported materials often depend on the degree of loading. Our interest in studying deposition of complexes onto solid supports is for the preparation of highly active and selective catalysts.

Over the last few decades, organometallic and transition metal coordination complexes have been used extensively for the synthesis of supported metal catalysts [5, 6, 8-14]. Supported catalysts generated in this way have advantages over those prepared using metal salts. For example, it is easier to control the attachment of the metal species to the surface and thereby obtain uniform distribution of the metal [5]. Mononuclear [10, 12, 15], dinuclear [13, 14], and polynuclear [5, 12] complexes have been deposited on supports. The interactions between the complexes and the support surface have been discussed and include ion exchange, hydrogen bonding, ligand substitution and metal coordination [11].

When supporting transition metal complexes on ceramic supports, a reaction leading to decomposition of the precursor compound can occur [16]. This decomposition precludes prediction of coverage based on precursor characteristics. Likewise, when di- and polynuclear complexes are supported on the surface and the interaction does not involve metal coordination, it is difficult to predict metal orientation on the surface [17]. As such, the current work attempts to deposit intact dinuclear complexes on the support surface through direct metal interactions with the support. This has the added benefit that the coverage of support can be predicted if the surface area of the support and the complex "footprint" area are known.

To facilitate the direct interaction of the metal and support surface, complexes with planar equatorial ligands are desirable. The overall geometry around the metal center can be octahedral, square pyramidal or square planar. If the geometry is octahedral, one of the axial ligands must be labile to substitution. Therefore, the preferred geometry around the metal is either square planar or square pyramidal. Copper(II) complexes form both of these geometries [18]. The equatorial ligands for the dinuclear copper(II) complexes are the triketonates [19] which are related to the ubiquitous acetylacetonate (acac) ligand [20, 21]. Specifically, bis(heptane-2,4,6-trionato)dicopper(II) $\left[\mathrm{Cu}_{2}(\mathrm{daa})_{2}\right] \quad[22-24]$ and bis(1,5-diphenyl-1,3,5pentanetrionato)dicopper(II) $\left[\mathrm{Cu}_{2}(\mathrm{dba})_{2}\right][24,25]$ will be used in this work.
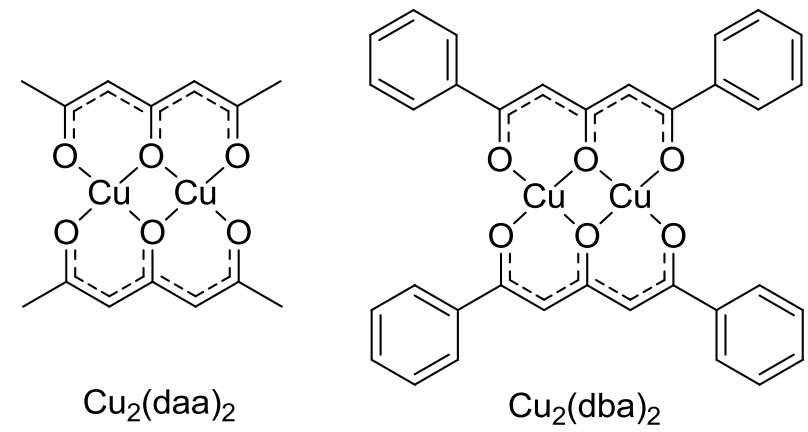

This paper describes research towards supporting $\mathrm{Cu}_{2}(\mathrm{daa})_{2}$ and $\mathrm{Cu}_{2}(\mathrm{dba})_{2}$ on silica using batch impregnation with the goal that the complex remains intact on the surface of the support. Characterization of the support with complexes adsorbed was performed using 
elemental analysis, thermal gravimetric analysis (TGA), diffuse reflectance infrared Fourier transform spectroscopy (DRIFTS), electron paramagnetic resonance (EPR) spectroscopy and powder X-ray diffraction (PXRD). These techniques are used to determine whether the complex is intact upon adsorption and, if intact, at what loading monolayer coverage is attained.

\section{Experimental}

\subsection{Chemicals}

Dehydroacetic acid, methylbenzoate, sodium hydride, barium hydroxide, pyridine and monoglyme were purchased from Sigma-Aldrich. Acetone and methylene chloride were obtained from Fisher Scientific. Tetrahydrofuran (THF, Fisher, 99\%) was dried over activated molecular sieves for $24 \mathrm{~h}$ prior to use. Copper acetate monohydrate (98\%) was obtained from Strem Chemicals. Cab-O-Sil (M-5 scintillation grade, $200 \mathrm{~m}^{2} / \mathrm{g}$ surface area) was purchased from ACROS Organics.

\subsection{Characterization techniques}

UV-vis spectra were recorded using a Shimadzu UV-2550 spectrometer over the 250-700 $\mathrm{nm}$ wavelength range. Measurements were performed in $1 \mathrm{~cm}$ quartz cuvettes with THF as the solvent for $\mathrm{Cu}_{2}(\text { daa })_{2}$ and $\mathrm{CH}_{2} \mathrm{Cl}_{2}$ as the solvent for $\mathrm{Cu}_{2}(\mathrm{dba})_{2}$.

Elemental analyses were performed by Galbraith Laboratories (Knoxville, Tennessee). All samples were analyzed for copper and carbon content.

A Thermo Nicolet 6700 spectrometer with a liquid nitrogen cooled MCT-A* detector controlled by Thermo Electron OMNIC software was used for collection of the DRIFTS spectra. Spectra were recorded with a $4 \mathrm{~cm}^{-1}$ resolution and averaged over 256 scans. Unsupported metal complexes were diluted in $\mathrm{KBr}$ powder (2 wt\%) with pure $\mathrm{KBr}$ used for background scans. Supported metal complexes were also diluted in $\mathrm{KBr}(5 \mathrm{wt} \%)$ for infrared analysis and $5 \mathrm{wt} \%$ $\mathrm{Cab}-\mathrm{O}-\mathrm{Sil}$ in $\mathrm{KBr}$ was used to obtain the background. A minimum of 3 spectra per sample were collected to confirm sample homogeneity.

PXRD patterns for supported and unsupported samples were collected by scanning $2 \theta$ over a $5-45^{\circ}$ range with a step width of $0.02^{\circ}$ using a Siemens D5000 instrument with Ni filtered $\mathrm{Cu}$ K $\alpha$ radiation $(\lambda=1.5406 \AA$ ). TGA was performed on $30-50 \mathrm{mg}$ of metal complexes supported on Cab-O-Sil and unsupported metal complexes using a ThermoFisher Scientific Versa Therm ${ }^{\mathrm{TM}}$ TGA instrument with helium flow. The temperature was increased from room temperature to $1000{ }^{\circ} \mathrm{C}$ at a rate of $5{ }^{\circ} \mathrm{C}$ per minute. EPR spectra were recorded on a Bruker EMX EPR spectrometer equipped with a $100 \mathrm{kHz}$ field modulator. Diphenylpicrylhydrazyl (DPPH) radical ( $g=2.007$ ) was used as reference.

X-ray crystallography was performed on a Bruker SMART1000 diffractometer which had been upgraded with an APEXII detector. Data acquisition, structure solution and refinement were performed using the APEX II software package [26] which incorporates aspects of SHELX.[27] Diffraction data were obtained at a sample temperature of $100 \mathrm{~K}$.

\subsection{Synthesis of ligands and metal complexes}


Heptane-2,4,6-trione $\left(\mathrm{H}_{2}\right.$ daa) was prepared by treatment of dehydroacetic acid with acid, isolation of the barium salt of the resulting dimethylpyrone followed by acidification according to a literature procedure [28]. A reported method involving double deprotonation of acetone with sodium hydride followed by treatment with two equivalents of methylbenzoate was used to synthesize 1,5-diphenyl-1,3,5-pentanetrione $\left(\mathrm{H}_{2} \mathrm{dba}\right)$ [29].

As described previously, $\mathrm{Cu}_{2}(\mathrm{daa})_{2}$ and $\mathrm{Cu}_{2}(\mathrm{dba})_{2}$ were prepared by treatment of $\mathrm{Cu}\left(\mathrm{CH}_{3} \mathrm{COO}\right)_{2} \cdot \mathrm{H}_{2} \mathrm{O}$ with $\mathrm{H}_{2}$ daa and $\mathrm{H}_{2}$ dba, respectively $[22,24]$. Both metal complexes were purified by recrystallization from pyridine. Coordinated pyridine ligands were removed from the resultant complexes under reduced pressure at $65{ }^{\circ} \mathrm{C}$ prior to attempted support of the complexes onto silica. Crystals of the dipyridine adduct of $\mathrm{Cu}_{2}(\mathrm{dba})_{2}$ suitable for crystallography were obtained by slow evaporation of a dipyridine solution of the complex.

\subsection{Support of dicopper complexes on Cab-O-Sil}

The desired mass $(0.020,0.025,0.035,0.050,0.060$ or $0.070 \mathrm{~g})$ of $\mathrm{Cu}_{2}(\mathrm{daa})_{2}$ was dissolved in $500 \mathrm{~mL}$ THF. $0.20 \mathrm{~g}$ of Cab-O-Sil was added and the mixture was stirred using a magnetic stir bar sealed in glass in a closed Erlenmeyer flask. After $24 \mathrm{~h}$, the silica with complexes supported were collected by filtration, washed with $100 \mathrm{~mL}$ of fresh THF and residual solvent was removed under reduced pressure for $6 \mathrm{~h}$ at room temperature.

Variable amounts of $(0.010,0.015,0.020,0.040,0.060$, and $0.080 \mathrm{~g}) \mathrm{Cu}_{2}(\mathrm{dba})_{2}$ were dissolved in $100 \mathrm{~mL}$ of $\mathrm{CH}_{2} \mathrm{Cl}_{2} .0 .25 \mathrm{~g} \mathrm{Cab}-\mathrm{O}$-Sil was added and the mixture stirred for $24 \mathrm{~h}$. The silica with complex adsorbed was collected and washed with two $50 \mathrm{~mL}$ aliquots of $\mathrm{CH}_{2} \mathrm{Cl}_{2}$. The silica with supported metal complex was subjected to reduced pressure for $6 \mathrm{~h}$ at room temperature to remove $\mathrm{CH}_{2} \mathrm{Cl}_{2}$.

\section{Results and Discussion}

\subsection{Support of $\mathrm{Cu}_{2}(\mathrm{daa})_{2}$ on silica}

The goal of this work was to deposit the dinuclear copper triketonate complexes onto silica intact with the expectation that the plane of the complex be parallel to the surface of the support. This was attempted using batch impregnation where the metal complex deposited on the support from solution. Unfortunately, $\mathrm{Cu}_{2}(\mathrm{daa})_{2}$ is insoluble or only slightly soluble in most non-coordinating or weakly coordinating organic solvents including methanol, ethanol, $\mathrm{CH}_{2} \mathrm{Cl}_{2}$, toluene, diethyl ether or dimethylsulfoxide. Besides pyridine, the only solvent in which this complex dissolves to any degree is THF. As such, solutions of $\mathrm{Cu}_{2}(\mathrm{daa})_{2}$ were prepared in this solvent and these were used for the batch impregnations. Cab-O-Sil was selected as the support because it is a fused silica with a specified surface area of $200 \mathrm{~m}^{2} / \mathrm{g}$. The lack of pores ensures that the deposition will be on the outer surface making characterization more straightforward. Likewise, the knowledge of the surface area allows for a prediction of the monolayer loading for the complexes. From the crystal structure of the dipyridine adduct of $\mathrm{Cu}_{2}(\mathrm{daa})_{2}$ [30], the footprint of this complex is $8.389 \times 8.931 \AA$. This results in an area of $7.49 \times 10^{-19} \mathrm{~m}^{2}$. Using the 


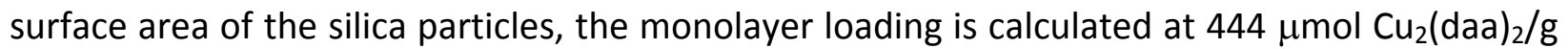
Cab-O-Sil which corresponds to a copper weight percent of $4.77 \%$.

Because it was of interest to generate silica with increasing metal loadings, solutions of different concentrations were used for the batch impregnations. As shown in Table 1, the mass of $\mathrm{Cu}_{2}$ (daa) ${ }_{2}$ dissolved in $500 \mathrm{~mL}$ of THF varied from 0.020 to $0.070 \mathrm{~g}$. The mass of Cab-O-Sil was constant at $0.20 \mathrm{~g}$ for these experiments. For each deposition, the silica was treated with the solution for $24 \mathrm{~h}$. The concentration of copper complex in solution could be readily monitored by UV-vis spectroscopy.

The absorption spectra for the deposition of $0.020 \mathrm{~g}$ of $\mathrm{Cu}_{2}(\mathrm{daa})_{2}$ on silica before and after the treatment are shown in Figure 1. The solution prior to addition of silica has an absorption peak at $350 \mathrm{~nm}$ corresponding to the dicopper triketonate. After $24 \mathrm{~h}$, the absorption corresponding to the complex is gone and a new shoulder appears at lower wavelength. This suggests that a species is formed in solution during the deposition process. Similar spectra were obtained for all reactions for supporting $\mathrm{Cu}_{2}(\mathrm{daa})_{2}$ on silica from THF solution.

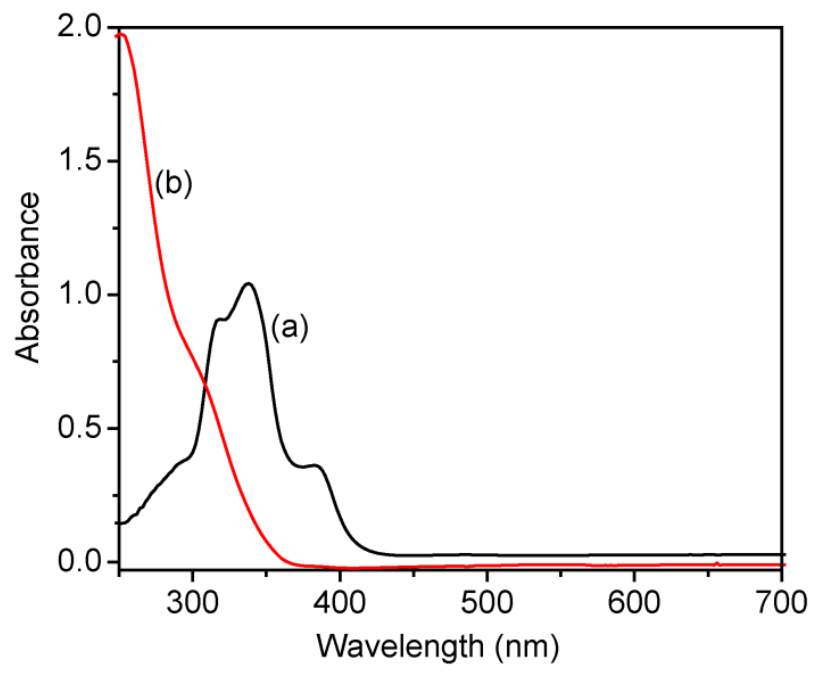

Figure 1. UV-vis spectrum of (a) $9.8 \times 10^{-5} \mathrm{M} \mathrm{Cu}_{2}(\text { daa })_{2}$ in THF [preparation of sample 1a] (b) the same solution after stirring with $0.20 \mathrm{~g}$ of Cab-O-Sil for $24 \mathrm{~h}$.

After deposition for $24 \mathrm{~h}$, the silica with complex supported was filtered, washed with additional solvent and placed under reduced pressure. The samples were submitted for elemental analysis to determine copper and carbon percentages. If the complex was deposited intact on the silica surface, the mole ratio of carbon to copper would correspond to that in the complex (7). Table 1 lists the results from elemental analysis of the six $\mathrm{Cu}_{2}(\mathrm{daa})_{2}$ samples. As expected, both the percent copper and percent carbon increase with increasing concentration of complex in the solution. However, while the mole ratio of carbon to copper is actually larger than for the complex in sample $1 \mathrm{a}$, this ratio for samples $1 \mathrm{c}$ to $1 \mathrm{f}$ is at a value approximately half that for an intact complex. Sample $1 \mathrm{~b}$ has a ratio intermediate corresponding to about three-quarters of the ligands present for each copper. 
Table 1. Copper and carbon weight percentages and resultant mole ratio of carbon to copper of silica-supported $\mathrm{Cu}_{2}(\mathrm{daa})_{2}$ from elemental analysis.

\begin{tabular}{|c|c|c|c|c|}
\hline Sample & $\begin{array}{c}\text { mass } \mathrm{Cu}_{2}(\mathrm{daa})_{2} \\
\text { dissolved }(\mathrm{g})^{\mathrm{a}}\end{array}$ & C weight\% & Cu weight\% & ${\mathrm{mol} \mathrm{C} / \mathrm{mol} \mathrm{Cu}^{\mathrm{b}}}$ \\
\hline $1 \mathrm{a}$ & 0.020 & 1.90 & 1.25 & 8.02 \\
\hline $1 \mathrm{~b}$ & 0.025 & 2.45 & 2.49 & 5.20 \\
\hline $1 \mathrm{c}$ & 0.035 & 3.02 & 4.43 & 3.60 \\
\hline $1 \mathrm{~d}$ & 0.050 & 4.01 & 5.98 & 3.55 \\
\hline $1 \mathrm{e}$ & 0.060 & 4.15 & 6.90 & 3.17 \\
\hline $1 \mathrm{f}$ & 0.070 & 5.19 & 7.53 & 3.66 \\
\hline
\end{tabular}

a) Treating solution prepared by dissolving this mass of complex in $500 \mathrm{~mL} \mathrm{THF}$.

b) If complex is intact, value of 7 expected.

To further characterize the composition on the silica, samples 1a-f were subjected to TGA under a helium atmosphere. Thermal decomposition of the unsupported $\mathrm{Cu}_{2}(\mathrm{daa})_{2}$ was also performed (Figure 2). This complex does not undergo any significant weight loss until $190{ }^{\circ} \mathrm{C}$. From $190{ }^{\circ} \mathrm{C}$ to $260^{\circ} \mathrm{C}$, a rapid loss of weight from the complex occurs. A second, slower weight percent decrease from $280^{\circ} \mathrm{C}$ to $440^{\circ} \mathrm{C}$ is then observed.

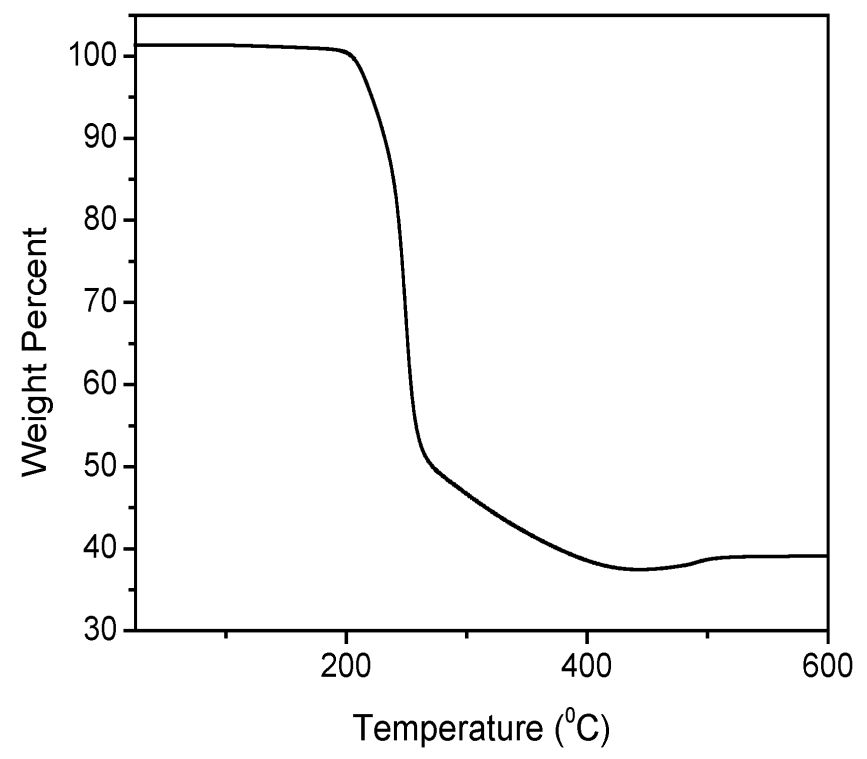

Figure 2. Thermogram for $\mathrm{Cu}_{2}(\mathrm{daa})_{2}$ 


$$
\begin{aligned}
& \underset{\mathrm{Cu}_{2}\left(\mathrm{C}_{7} \mathrm{H}_{8} \mathrm{O}_{3}\right)_{2}(\mathrm{~s}) \stackrel{\Delta}{\longrightarrow}}{\mathrm{Cu}_{2}(\text { daa })_{2}} 2 \mathrm{Cu}(\mathrm{OH})_{2}(\mathrm{~s})+\begin{array}{r}
\text { volatile } \\
\text { species }
\end{array} \\
& 2 \mathrm{Cu}(\mathrm{OH})_{2}(\mathrm{~s}) \stackrel{\Delta}{\longrightarrow} 2 \mathrm{CuO}(\mathrm{s})+2 \mathrm{H}_{2} \mathrm{O}(\mathrm{g})
\end{aligned}
$$

These results can be rationalized by Equations 1 and 2. The calculated weight loss for the first reaction is $52.1 \%$ in agreement with the TGA results. The second reaction, which is known to occur readily at modest temperatures [31], yields a predicted weight loss of $8.8 \%$ which agrees with the observed weight loss of $9 \%$. The TGA data suggest that most of the daa ligands are volatized at temperatures below $280^{\circ} \mathrm{C}$.

Table 2. Experimental \% weight loss from TGA for silica-supported $\mathrm{Cu}_{2}(\mathrm{daa})_{2}$ samples and calculated \% weight loss assuming complex intact on surface

\begin{tabular}{|c|c|c|c|}
\hline Sample & weight\% Cu & \% weight loss (calc.) & \% weight loss (exp.) \\
\hline $1 \mathrm{a}$ & 1.25 & 2.44 & 3 \\
\hline $1 \mathrm{~b}$ & 2.49 & 4.97 & 4 \\
\hline $1 \mathrm{c}$ & 4.43 & 8.84 & 5 \\
\hline $1 \mathrm{~d}$ & 5.98 & 11.9 & 6 \\
\hline $1 \mathrm{e}$ & 6.90 & 13.7 & 6 \\
\hline $1 \mathrm{f}$ & 7.53 & 15.0 & 8 \\
\hline
\end{tabular}

a) Calculated from weight\% $\mathrm{Cu}$ assuming complex remains intact

The thermal decomposition results for the silica supported $\mathrm{Cu}_{2}(\mathrm{daa})_{2}$ samples are reported in Table 2. Using the weight\% Cu obtained from elemental analysis, the predicted weight loss if the complex remains intact are given in the third column of this table. The weight loss observed for sample $1 \mathrm{a}$ is slightly higher than the calculated value in agreement with the elemental analysis for carbon. All of the other samples produced lower \% weight losses than the calculated values indicating there is a loss of volatile components from the adsorbed metal complex. For samples $1 \mathrm{c}, 1 \mathrm{~d}, 1 \mathrm{e}$ and $1 \mathrm{f}$, the experimental \% weight loss is approximately half of that calculated from the weight\% $\mathrm{Cu}$.

The elemental analysis and TGA results for samples $1 \mathrm{c}, 1 \mathrm{~d}, 1 \mathrm{e}$ and $1 \mathrm{f}$ clearly suggest a loss of one triketonate ligand from the $\mathrm{Cu}_{2}(\mathrm{daa})_{2}$ complex upon adsorption on silica. It is postulated that upon interaction with the silanol groups on the surface of the silica, the triketonate is protonated and decoordinates from the copper centers. The copper(II) ions then complex with the deprotonated silanol sites on the surface (equation 3) similar to what occurs when $\mathrm{Mn}(\mathrm{acac})_{3}$ is deposited on alumina [32]. 


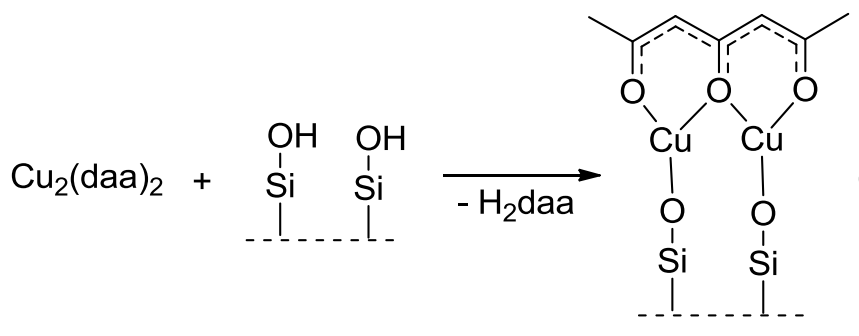

Both elemental analysis and TGA suggest that both triketonate ligands are present in sample $1 \mathrm{a}$ and that in sample $1 \mathrm{~b}$, there is between one and two triketonates for each dicopper unit. The possible explanations for these results are that the complex remains intact at very low loadings or that the complex decomposes according to Equation 3, but that the $\mathrm{H}_{2}$ daa is then adsorbed on the silica surface. As discussed below, DRIFTS supports the second explanation.

The loss of a ligand from a metal complex upon deposition has been reported previously. Bruce et al. described a bis(diethanolamine) copper complex , $\left[\mathrm{CuC}_{8} \mathrm{H}_{21} \mathrm{~N}_{2} \mathrm{O}_{4}\right]^{+}$, that loses a ligand upon decoration of a Cab-O-Sil surface [17]. For loadings in excess of a monolayer, the extra monolayer complexes did not lose a ligand upon deposition to the surface. For the current complex, studies were not performed to determine whether at greater than a monolayer loading complexes in the second layer would remain intact.

DRIFTS was used to investigate the IR vibrations of unsupported $\mathrm{Cu}_{2}(\mathrm{daa})_{2}$ and the silica surface obtained when this complex is allowed to react with silica in THF (Figure 3 ). Examination of the region between $1800 \mathrm{~cm}^{-1}$ and $1300 \mathrm{~cm}^{-1}$ confirms that the surface does not have intact $\mathrm{Cu}_{2}(\mathrm{daa})_{2}$ supported. Unsupported $\mathrm{Cu}_{2}(\text { daa })_{2}$ has peaks at $1360,1408,1464$, and $1540 \mathrm{~cm}^{-1}$. In all spectra of treated silica samples, these peaks are missing and other peaks are present. Note that in sample $1 \mathrm{~b}$, the peaks correspond to those of the higher loading of metal suggesting the same surface bound species is present. For sample 1a, the peaks are rather weak but there is no indication that intact $\mathrm{Cu}_{2}(\text { daa })_{2}$ is adsorbed on the surface. This spectroscopic evidence supports the hypothesis that the complex decomposes and that the carbon/volatile species present is due to adsorbed triketone.

In all silica supported samples a broad intense peak is present at $1013 \mathrm{~cm}^{-1}$. This peak is shifted from the value for Si-O vibrations in pure silica gel which occurs at $1086 \mathrm{~cm}^{-1}$ [33]. This shift was observed previously in the infrared spectra of mixed Si/M oxide systems including where $\mathrm{M}=\mathrm{Cu}$ [33]. This supports the formulation of the samples as having Si-O-Cu bridges. 


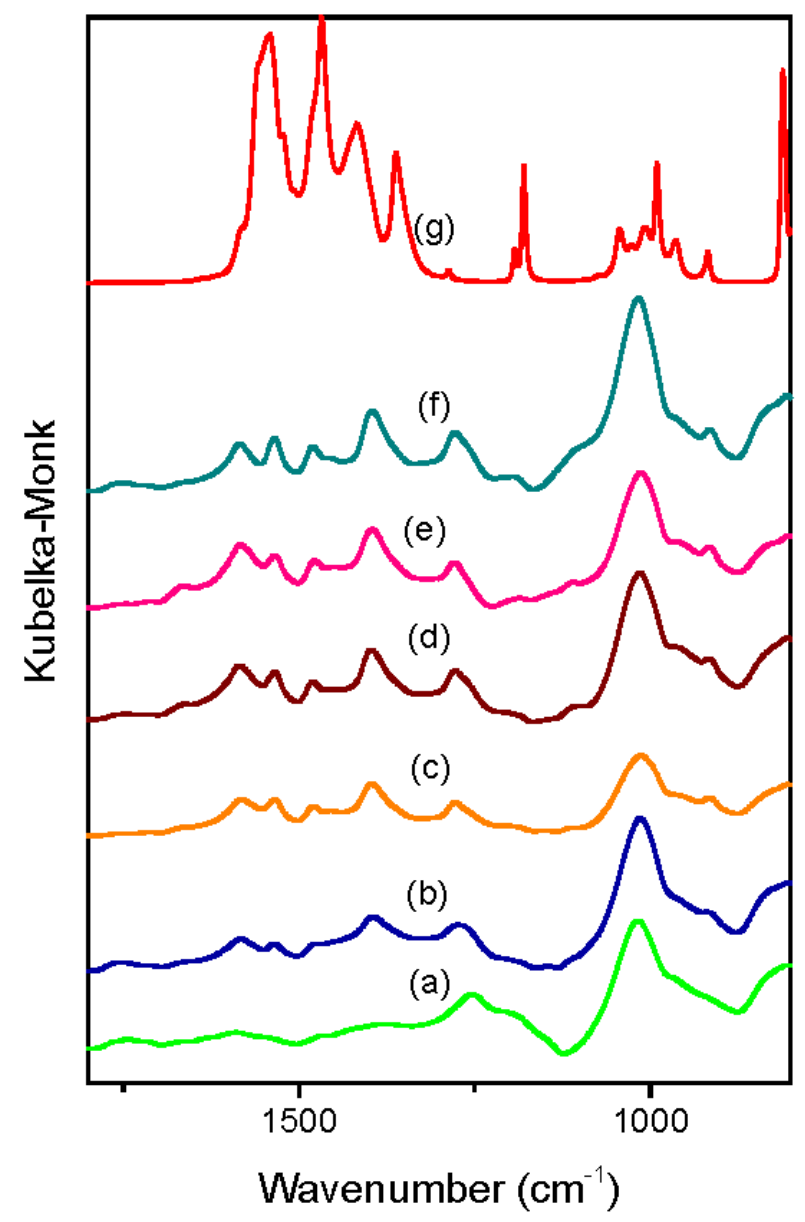

Figure 3. DRIFTS of $\mathrm{Cu}_{2}(\mathrm{daa})_{2} /$ silica at copper loadings of (a) sample $1 \mathrm{a}$ (b) sample $1 \mathrm{~b}$ (c) sample $1 \mathrm{c}(\mathrm{d})$ sample $1 \mathrm{~d}(\mathrm{e})$ sample $1 \mathrm{e}(\mathrm{f})$ sample $1 \mathrm{f}$, and $(\mathrm{g})$ unsupported $\mathrm{Cu}_{2}(\mathrm{daa})_{2}$. 


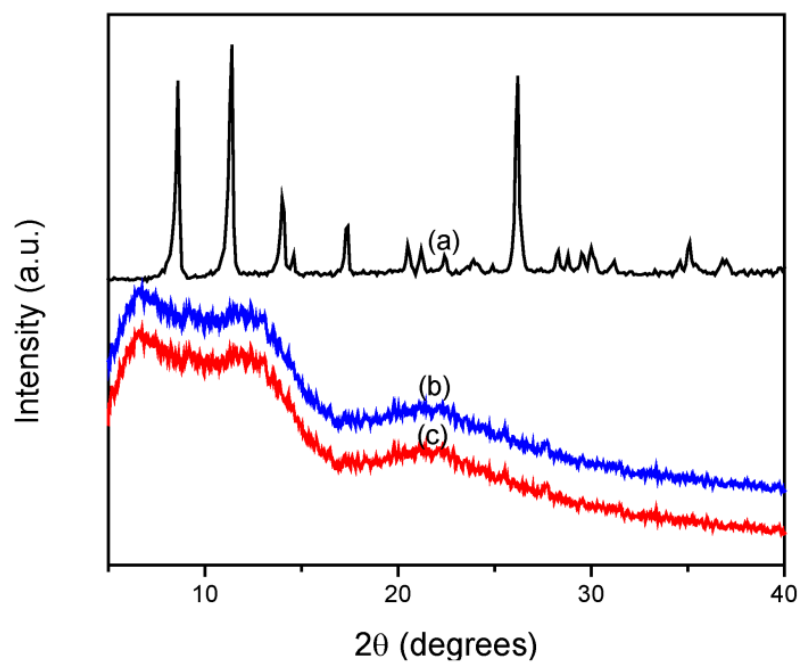

Figure 4. PXRD of (a) unsupported $\mathrm{Cu}_{2}(\mathrm{daa})_{2}$ (b) sample $1 \mathrm{a}(\mathrm{c})$ sample $1 \mathrm{f}$

Even though $\mathrm{Cu}_{2}(\mathrm{daa})_{2}$ is not deposited on silica intact, it was still of interest to determine whether the metal supported surface had any crystalline character by PXRD. As illustrated in Figure 4, unsupported $\mathrm{Cu}_{2}(\mathrm{daa})_{2}$ is polycrystalline and shows sharp, intense peaks in the PXRD at $2 \theta$ values of $6.52,9.55,10.30,12.79,14.44,17.40,20.16,22.02,22.64,25.47,27.54$ and 29.26 degrees. As exemplified by diffractograms for samples $1 \mathrm{a}$ and $1 \mathrm{f}$ in Figure 4 , none of the treated silica gave any diffraction peaks except for the broad patterns associated with silica gel. This suggests that there is no crystalline character for these samples.

Attempts to deposit $\mathrm{Cu}_{2}(\text { daa })_{2}$ from THF solution onto silica intact were unsuccessful. The complex lost one of the triketonate ligands upon interaction with the surface giving a siloxidebound metal complex with one triketonate ligand. With no other viable options for solvent to use, another dicopper triketonate complex, $\mathrm{Cu}_{2}(\mathrm{dba})_{2}$, was evaluate as a precursor for deposition of an intact metal complex onto silica.

\subsection{Molecular structure of the dipyridine adduct of $\mathrm{Cu}_{2}(\mathrm{dba})_{2}$}

Unlike $\mathrm{Cu}_{2}(\mathrm{daa})_{2}$, the crystal structure of the dipyridine adduct of $\mathrm{Cu}_{2}(\mathrm{dba})_{2}$ has not been reported. Therefore, it was necessary to obtain the crystal structure of the complex so that the footprint of the equatorial plane could be determined. Crystals suitable for diffractometry were grown by slow evaporation of a pyridine solution of the complex. The molecular structure obtained by crystallography is shown in Figure \#. 

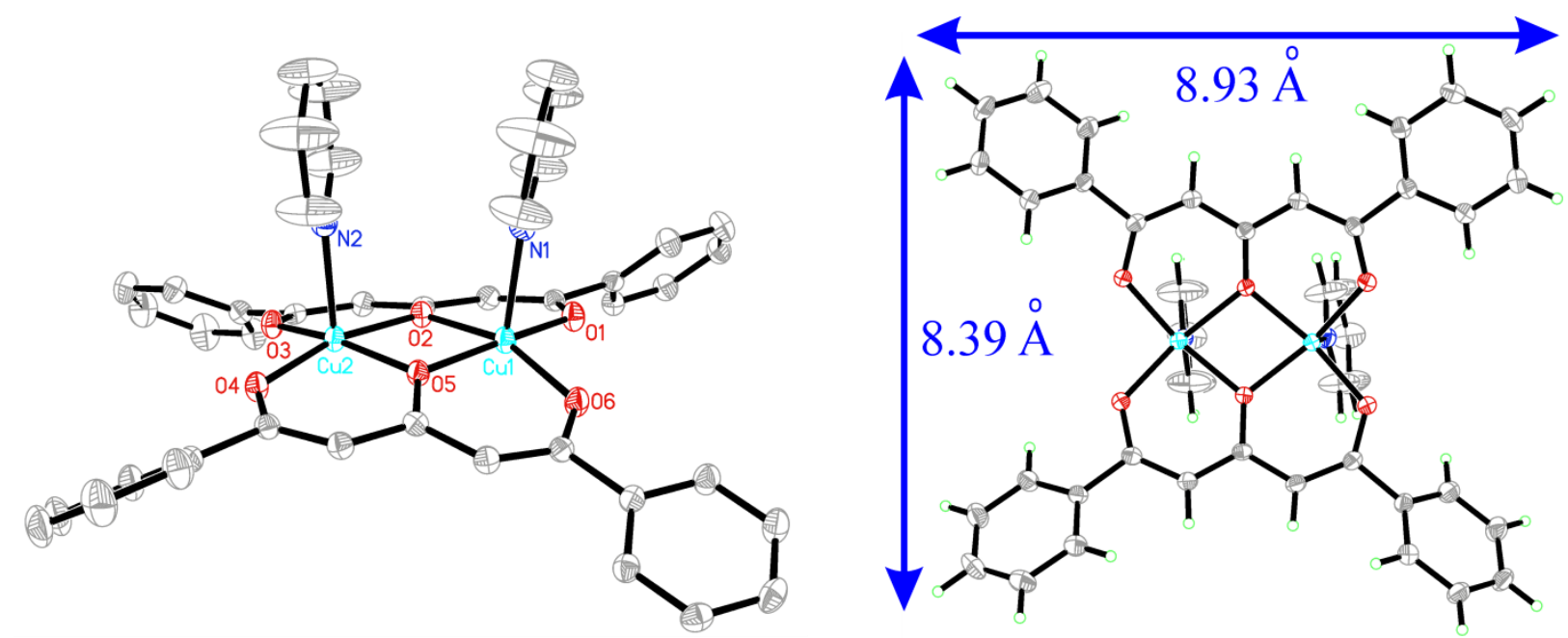

Figure \#. Thermal ellipsoid (50\% probability) drawing of the cis dipyridine adduct of $\mathrm{Cu}_{2}(\mathrm{dba})_{2}$. Disordered pyridine and hydrogen atoms removed for clarity (left). View of the complex from below the equatorial plane showing the footprint area (right).

In contrast to all seven previous structures of dipyridine adducts of dicopper bis(triketonate) complexes, [30, 34-40] the pyridine ligands are coordinated to the metal centers on the same face of the $\mathrm{Cu}_{2}$ (triketonate) ${ }_{2}$ unit in this complex. However, three dicopper triketonate complexes with nitrogen donor ligands in the axial positions have been structurally characterized where the ligands are coordinated to the same face.[34, 35] In these complexes, the nitrogen donor ligand is a 1-substituted pyrazine group. The alkyl substituent bound to the $\alpha$-nitrogen atom of the heterocyclic ring imparts steric constraint between this ligand and the dicopper triketonate moiety.

An analysis of the compounds with cis axial substitution suggests that this configuration allows for relief of steric interactions between the axial ligands and the triketonate groups. This occurs because the triketonates can fold away from the axial ligands. The extent of this folding can be evaluated by the angle between the planes of the 5 carbon atoms and 3 oxygen atoms for the two triketonate ligands. In the cis dipyrazine compounds this parameters varies from 6.7 to 22.2 degrees. For $\mathrm{Cu}(\mathrm{dba})_{2}(\mathrm{py})_{2}$, this angle is even more pronounced at $25.74(0.05)$ degrees.

In light of the other dipyridine adducts that have been structurally characterized in the trans configuration, it is not readily apparent as to the cause of the steric demands associated with the dipyridine adduct of $\mathrm{Cu}_{2}(\mathrm{dba})_{2}$ that leads to a cis orientation. In particular, it is not obvious as to why this complex with phenyl substituents would adopt the cis geometry while the complex with para-methoxyphenyl-substituted triketonate ligands [trans- $\mathrm{Cu}_{2}(\mathrm{dana})_{2}(\mathrm{py})_{2}$ ] is trans.[39] 


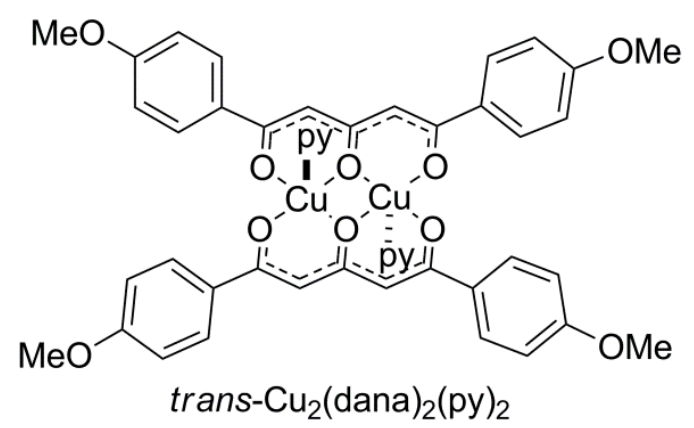

A space filling model clearly indicates that the 2,6 hydrogen atoms of the pyridine ligand will contact the ortho hydrogen atoms of the phenyl groups in orientations where the phenyl group is perpendicular to the $\mathrm{Cu}_{2}(\mathrm{dba})_{2}$ plane. This interaction will not be present with non-sterically demanding alkyl substituents. However, the above interaction would be present for the paramethoxyphenyl derivative if in a similar orientation.

While the crystal structure only represents the situation in the solid, a comparison of these for $\operatorname{cis}-\mathrm{Cu}_{2}(\mathrm{dba})_{2}(\mathrm{py})_{2}$ and trans- $\mathrm{Cu}_{2}(\mathrm{dana})_{2}(\mathrm{py})_{2}$ give an indication as to the difference in steric demand for them. In the former, the angles between the planes of the phenyl groups and the two carbon and one oxygen atom of the triketonate framework to which they are attached are $39.77(0.15), 30.97(0.25), 36.23(0.11)$ and $10.06(0.29)$ degrees. The corresponding angles for the para-methoxyphenyl derivative are 5.92 and 12.73 degrees. This suggests that the phenyl groups in the methoxyphenyl derivative have much more of a preference for coplanarity with the $\mathrm{Cu}_{2}$ (triketonate) $)_{2}$ group than in $c i s-\mathrm{Cu}_{2}(\mathrm{dba})_{2}(\mathrm{py})_{2}$.

The increased tendancy for planarity in trans- $\mathrm{Cu}_{2}(\text { dana })_{2}(\mathrm{py})_{2}$ over $c i s-\mathrm{Cu}_{2}(\mathrm{dba})_{2}(\mathrm{py})_{2}$ is due to the enhanced ability of the para-methoxyphenyl group to conjugate with $\pi$ systems resulting in electron donation. In the former, the bonds between $\mathrm{Cu}$ centers and oxygen atoms of the triketonate are shorter than in the latter. Likewise, the bond between the ipso carbon atom of the phenyl group forms a shorter bond with the terminal carbon of the triketonate group in the methoxyphenyl derivative. These structural features all support the hypothesis that an enhanced conjugation between the phenyl groups and the remainder of the complex is operative in trans- $\mathrm{Cu}_{2}(\text { dana })_{2}(\mathrm{py})_{2}$ when compared with cis- $\mathrm{Cu}_{2}(\mathrm{dba})_{2}(\mathrm{py})_{2}$.

One other very interesting structural feature in $c i s-\mathrm{Cu}_{2}(\mathrm{dba})_{2}(\mathrm{py})_{2}$ should be highlighted. The planes of the pyridine ligands are approximately perpendicular to the $\mathrm{Cu}-\mathrm{Cu}$ axis. If a plane is defined that includes both copper centers and the nitrogen of the coordinated pyridine, the angles between the planes are $81.06(0.11)$ and $83.94(0.12)$ degrees. In the structures of the other dipyridine adducts, these angles are between 20.0 and 39.7 degrees. Therefore, the trans dipyridines have the plane of the pyridines approximately collinear with terminal oxygencopper-bridging oxygen axis while in $c i s-\mathrm{Cu}_{2}(\mathrm{dba})_{2}(\mathrm{py})_{2}$ the pyridine plane is 45 degrees to these axes.

\subsection{Characterization of silica supported $\mathrm{Cu}_{2}(\mathrm{dba})_{2}$ complexes}

$\mathrm{Cu}_{2}(\mathrm{dba})_{2}$ dissolves in most common organic solvents. $\mathrm{CH}_{2} \mathrm{Cl}_{2}$ was chosen as the solvent for $\mathrm{Cu}_{2}(\mathrm{dba})_{2}$ deposition as it does not strongly coordinate to the metal thereby permitting the axial positions of the metal to be available for strong interactions with the support. 0.010 to $0.080 \mathrm{~g}$ of $\mathrm{Cu}_{2}(\mathrm{dba})_{2}$ was dissolved in $100 \mathrm{~mL}$ of this solvent and $0.25 \mathrm{~g}$ of Cab-O-Sil added. 
These amounts of complex were chosen as they gave a good range about the calculated monolayer loading of $193 \mu \mathrm{mol} / \mathrm{g} \mathrm{SiO} \mathrm{S}_{2}$ corresponding to a 2.19\% copper loading. The dimensions of the $\mathrm{Cu}_{2}(\mathrm{dba})_{2}[12.879 \times 13.408 \AA]$ were obtained from the crystal structure of the dipyridine adduct.

Deposition of the metal complex onto Cab-O-Sil was monitored by UV-vis spectroscopy of the metal complex solution before and $24 \mathrm{~h}$ after addition of Cab-O-Sil. As shown in Figure 5, the spectrum of the $\mathrm{Cu}_{2}(\mathrm{dba})_{2}$ solution used for deposition had no additional peaks following deposition. This suggests that the parent metal complex does not undergo decomposition such as ligand dissociation during the deposition process.

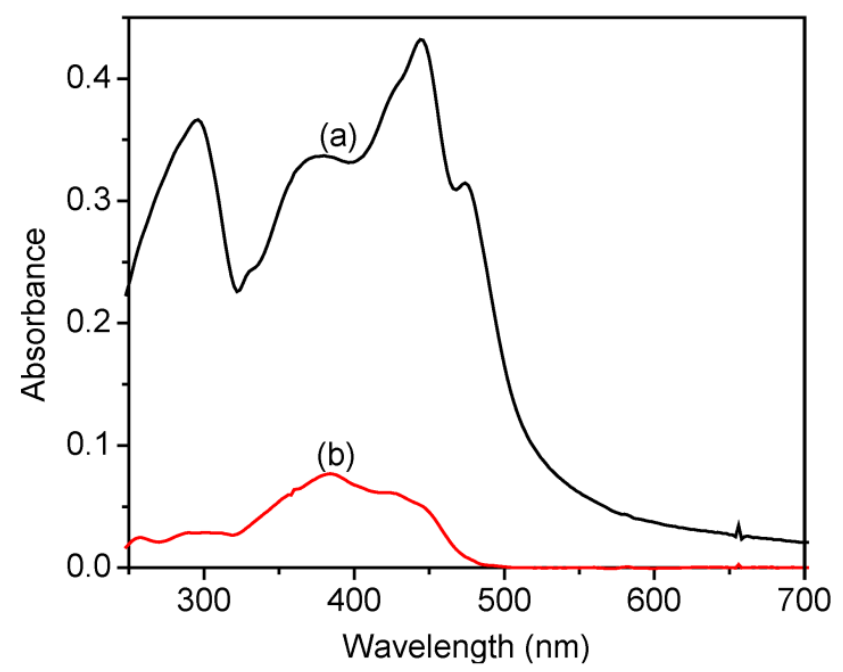

Figure 5. UV-vis spectra of (a) $1.5 \times 10^{-4} \mathrm{M} \mathrm{Cu}_{2}(\mathrm{dba})_{2}$ in $\mathrm{CH}_{2} \mathrm{Cl}_{2}$ [preparation of sample 2a] (b) after stirring the solution with $0.25 \mathrm{~g}$ of Cab-O-Sil for $24 \mathrm{~h}$.

The change in UV-vis absorbance at $444 \mathrm{~nm}$ of $\mathrm{Cu}_{2}(\mathrm{dba})_{2}$ was used to calculate the amount of metal complex deposited onto the Cab-O-Sil. The calculated wt\% of carbon and copper are given in Table 3. To determine whether the ligands remained intact on the surface after the adsorption of each metal complex, copper and carbon elemental analysis was performed and these results are also listed. Note that the predictions from UV-vis spectral analysis agree with the elemental analysis results.

Table 3. Copper and carbon weight percentages from elemental analysis, those calculated from UV-vis spectroscopy and $\mathrm{mol} \mathrm{C/mol} \mathrm{Cu} \mathrm{ratio} \mathrm{for} \mathrm{silica} \mathrm{supported} \mathrm{Cu}_{2}(\mathrm{dba})_{2}$.

\begin{tabular}{|c|c|c|c|c|c|c|}
\hline \multirow[t]{2}{*}{ Sample } & \multirow{2}{*}{$\begin{array}{c}\text { Mass } \\
\mathrm{Cu}_{2}(\mathrm{dba})_{2} \\
\text { dissolved } \\
(\mathrm{g})^{\mathrm{a}}\end{array}$} & \multicolumn{2}{|c|}{$\begin{array}{c}\text { Composition by } \\
\text { elemental analysis }\end{array}$} & \multicolumn{2}{|c|}{$\begin{array}{c}\text { Calculated } \\
\text { composition from UV- } \\
\text { vis spectroscopy }\end{array}$} & \multirow[t]{2}{*}{$\mathrm{mol} \mathrm{C} / \mathrm{mol} \mathrm{Cu}^{\mathrm{b}}$} \\
\hline & & $\% \mathrm{Cu}$ & $\% \mathrm{C}$ & $\% \mathrm{Cu}$ & $\% \mathrm{C}$ & \\
\hline $2 a$ & 0.010 & 0.73 & 2.36 & 0.73 & 2.3 & 17 \\
\hline
\end{tabular}




\begin{tabular}{|c|c|c|c|c|c|c|}
\hline $2 \mathrm{~b}$ & 0.015 & 1.06 & 3.62 & 1.1 & 3.5 & 18.0 \\
\hline $2 \mathrm{c}$ & 0.020 & 1.36 & 4.47 & 1.3 & 4.3 & 17.4 \\
\hline $2 \mathrm{~d}$ & 0.040 & 2.64 & 8.11 & 2.6 & 8.5 & 16.3 \\
\hline $2 \mathrm{e}$ & 0.060 & 3.91 & 11.9 & 3.7 & 12 & 16.1 \\
\hline $2 \mathrm{f}$ & 0.080 & 4.34 & 13.8 & 4.6 & 14 & 16.8 \\
\hline
\end{tabular}

a) Treating solution prepared by dissolving this mass of complex in $100 \mathrm{~mL} \mathrm{CH}_{2} \mathrm{Cl}_{2}$.

b) If complex is intact, value of 17 expected.

Using the copper and carbon wt\% found by elemental analysis (Table 3), $\mathrm{mol} \mathrm{C/mol} \mathrm{Cu}$ ratios were calculated for supported samples of $\mathrm{Cu}_{2}(\mathrm{dba})_{2}$. The average value for this ratio, mol $\mathrm{C} / \mathrm{mol} \mathrm{Cu}$, was 16.9 and the standard deviation in these data was 0.7 . The parent metal complex, $\mathrm{Cu}_{2}(\mathrm{dba})_{2}$, has a $\mathrm{C} / \mathrm{Cu}$ ratio of 17 . The agreement between the observed and predicted $\mathrm{C} / \mathrm{Cu}$ ratios suggests that the $\mathrm{Cu}_{2}(\mathrm{dba})_{2}$ complex is intact upon deposition on the Cab-O-Sil.

$\mathrm{Cu}_{2}(\mathrm{dba})_{2}$ was subjected to TGA under a stream of helium to determine the percent weight loss as a function of temperature. Expected weight changes were calculated for the unsupported sample assuming Equations 4 and 2 describe the process. The overall percent loss is predicted to be $70.2 \%$.

$$
\underset{\substack{\mathrm{Cu}_{2}\left(\mathrm{C}_{17} \mathrm{H}_{12} \mathrm{O}_{3}\right)_{2}(\mathrm{~s}) \stackrel{\Delta}{\rightarrow} \\ \mathrm{Cu}_{2}(\mathrm{dba})_{2}}}{\mathrm{Cu}(\mathrm{OH})_{2}(\mathrm{~s})+\underset{\text { volatile }}{\text { species }}}
$$

However, if the decomposition stops at Equation 4, the predicted weight loss is $70.2 \%$. Experimental weight changes of unsupported $\mathrm{Cu}_{2}(\mathrm{dba})_{2}$ were consistent with the reactions shown above. The $\mathrm{Cu}_{2}(\mathrm{dba})_{2}$ complex shows two weight loss events: (1) from $235{ }^{\circ} \mathrm{C}$ to $290{ }^{\circ} \mathrm{C}$ $(47 \%)$ and (2) above $290{ }^{\circ} \mathrm{C}(23 \%)$ as shown in Figure 6 . This total weight loss $(70 \%)$ is slightly less than calculated (70.2\%) when one assumes that the decomposition of $\mathrm{Cu}_{2}(\mathrm{dba})_{2}$ is described by Equation 4. 


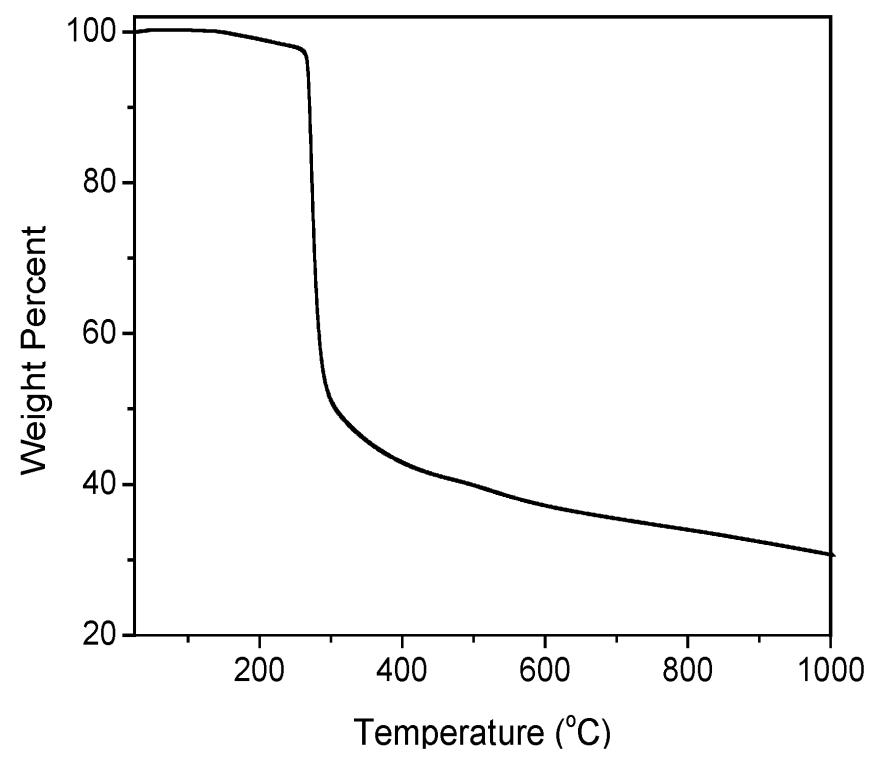

Figure 6. Thermogram for $\mathrm{Cu}_{2}(\mathrm{dba})_{2}$

The supported $\mathrm{Cu}_{2}(\mathrm{dba})_{2} /$ silica samples were examined by TGA and the weight percent versus temperature are shown in Figure 7. The predicted \%weight loss and experimental \%weight loss assuming the formation of $\mathrm{Cu}_{2} \mathrm{O}$ (with $2 \mathrm{O}-\mathrm{Si}$ also coordinated) on the surface are tabulated in Table 4. The root-mean-square deviation between predicted and observed weight loss was $1.1 \%$. Two other models of the decomposition were tested for which the final coppercontaining products were $\mathrm{CuO}$ and $\mathrm{Cu}(\mathrm{OH})_{2}$. The RMS deviations for these models were $1.11 \%$ and $1.5 \%$, respectively. These deviations do not suggest one model over another; however, the $\mathrm{Cu}_{2} \mathrm{O}$ model is selected over the other two on the basis of chemical principles of bonding structures observed for copper cations. After thermal decomposition, it is expected that these two copper atoms are attached to the oxygen atoms of the silanol groups and bridged by another oxygen atom as illustrated in Equation 5 and this was the basis for calculations.

$$
\mathrm{Cu}_{2}(\mathrm{dba})_{2}(\mathrm{ads}) \stackrel{\Delta}{\longrightarrow} \mathrm{Cu}_{2} \mathrm{O}\left(\mathrm{OSi}_{\text {surface }}\right)_{2}(\mathrm{~s})+\begin{gathered}
\text { volatile } \\
\text { species }
\end{gathered}
$$




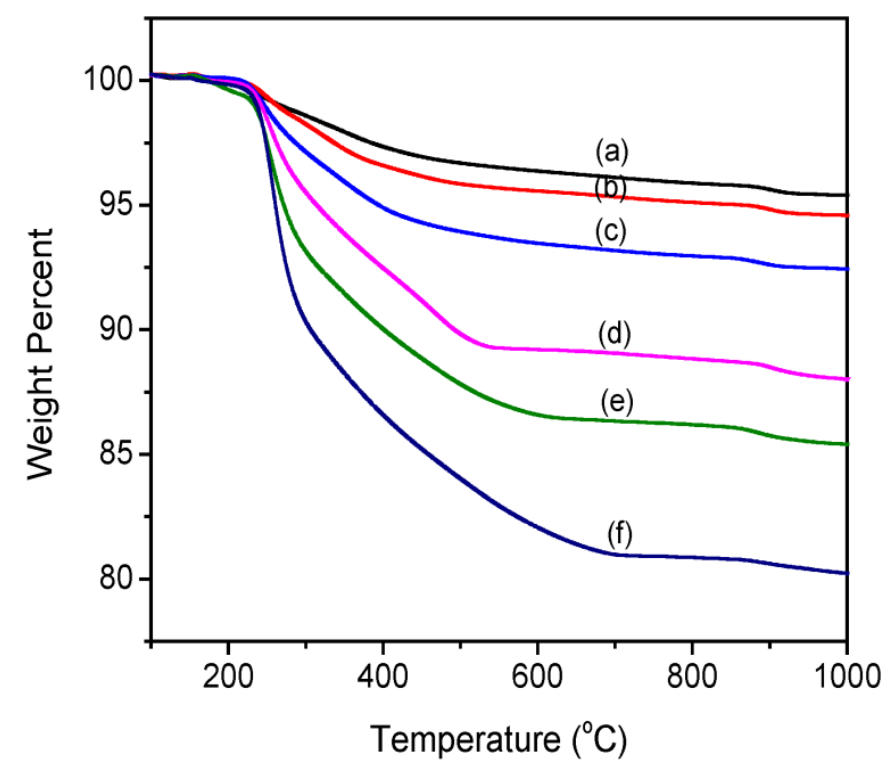

Figure 7. Thermograms for $\mathrm{Cu}_{2}(\mathrm{dba})_{2} /$ silica; (a) sample 2a (b) sample $2 \mathrm{~b}$ (c) sample 2c (d) sample $2 d(e)$ sample $2 e(f)$ sample $2 f$

Samples $2 \mathrm{a}, 2 \mathrm{~b}$ and $2 \mathrm{c}$ show very slow decomposition kinetics above $235^{\circ} \mathrm{C}$. Conversely, samples $2 \mathrm{~d}, 2 \mathrm{e}$ and $2 \mathrm{f}$ exhibit a rapid weight change from $235^{\circ} \mathrm{C}$ to $290{ }^{\circ} \mathrm{C}$ and a slow weight change above $290{ }^{\circ} \mathrm{C}$. Samples 2a-2c show Cu metal loadings expected for samples having submonolayer coverages of the supported metal complexes; whereas, samples $2 \mathrm{~d}-2 \mathrm{f}$ show $\mathrm{Cu}$ loadings expected for greater than monolayer coverages of the metal complex. This rapid weight change in samples $2 \mathrm{~d}-2 \mathrm{f}$ can be attributed to the decomposition of less strongly interacting second layer on the surface. The metal complexes in the second layer may show decomposition kinetics not unlike that of the polycrystalline sample, Figure 6 . The layer which lies close to the surface may be strongly attracted to the surface, hence, its decomposition kinetics may be different from that of the polycrystalline sample. These results for the $\mathrm{Cu}$ triketonate system are similar to those reported by Kenvin who examined the decomposition kinetics of a related, silica-supported $\mathrm{Cu}(\mathrm{acac})_{2}$ by TGA [41]. He showed that the decomposition kinetics of metal complexes residing in the monolayer were slower than the decomposition kinetics of the metal complexes found in the second and higher layers.

Table 4. Calculated and experimentally determined $\%$ weight loss of $\mathrm{Cu}_{2}(\mathrm{dba})_{2} /$ silica from TGA.

\begin{tabular}{|c|c|c|}
\hline Sample & \% weight loss (calc.) & \% weight loss (exp.) \\
\hline $2 \mathrm{a}$ & 2.91 & 4 \\
\hline $2 \mathrm{~b}$ & 4.27 & 4 \\
\hline $2 \mathrm{c}$ & 5.48 & 7 \\
\hline $2 \mathrm{~d}$ & 10.6 & 11 \\
\hline $2 \mathrm{e}$ & 15.8 & 14 \\
\hline $2 \mathrm{f}$ & 17.5 & 18 \\
\hline
\end{tabular}


Beckler and White demonstrated that PXRD could be used to determine the monolayer loading of metal complexes on the surface of an amorphous support [42]. Submonolayer loadings of a polynuclear metal complex on Cab-O-Sil resulted in no X-ray diffraction, whereas, a diffractogram containing a number of peaks was observed for a sample having more than a monolayer loading of the metal complex. The same analysis was performed on the silica samples decorated with $\mathrm{Cu}_{2}(\mathrm{dba})_{2}$.

Samples $2 a, 2 b$ and $2 c$ have no diffraction peaks in the PXRD except for the background from the silica. Sample $2 f$ has PXRD peaks at $2 \theta$ values of $6.52,9.56,10.30,12.80,14.44,17.40$, $20.16,22.02,22.64,25.48,27.54$, and 29.26 degrees. This means that it's diffraction is essentially identical with the pattern for $\mathrm{Cu}_{2}(\mathrm{dba})_{2}$ (Figure $8 \mathrm{~g}$ ). The onset of diffraction peaks occurs for sample $2 \mathrm{~d}$ and the intensity increases for sample 2e. The appearance of these peaks in sample $2 \mathrm{~d}$ suggests that at a metal loading of $2.64 \%$, a monolayer of deposited complex has been achieved.

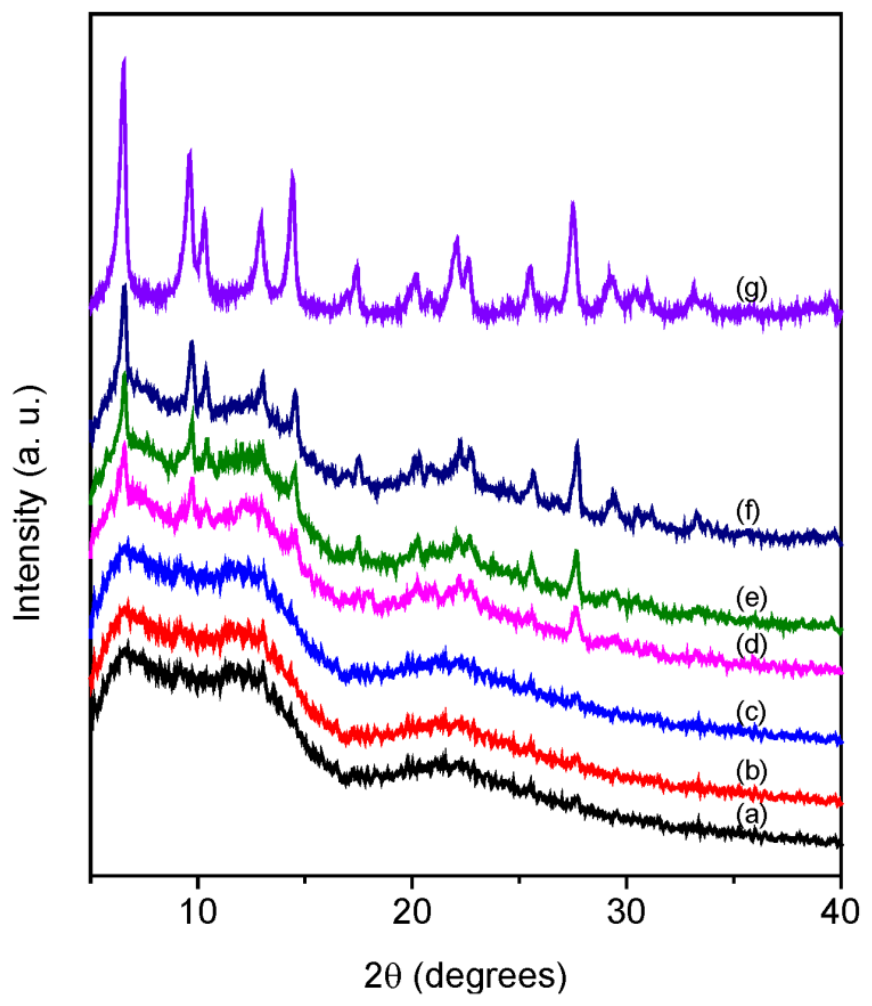

Figure 8. PXRD patterns of supported $\mathrm{Cu}_{2}(\mathrm{dba})_{2}$, (a) sample $2 \mathrm{a}(\mathrm{b})$ sample $2 \mathrm{~b}$ (c) sample $2 \mathrm{c}(\mathrm{d})$ sample $2 \mathrm{~d}(\mathrm{e})$ sample $2 \mathrm{e}(\mathrm{f})$ sample $2 \mathrm{f}$, and $(\mathrm{g})$ unsupported $\mathrm{Cu}_{2}(\mathrm{dba})_{2}$.

The DRIFTS spectra (Figure 9) of unsupported and Cab-O-Sil supported $\mathrm{Cu}_{2}(\mathrm{dba})_{2}$ at different $\mathrm{Cu}$ loadings further confirms that the complex is deposited intact and also allows for a determination of complete monolayer formation. Evidence that the complex deposits intact on 
silica is the similarity of the spectra for the supported samples to those of the parent metal complex. However, there are very subtle, but important differences between the spectra of the supported samples and the parent complex. In the spectra of samples $2 \mathrm{a}, 2 \mathrm{~b}$ and $2 \mathrm{c}$, peaks are absent that are present for higher metal loaded samples. For example, the peak at $1488 \mathrm{~cm}^{-1}$ is not present for samples $2 \mathrm{a}, 2 \mathrm{~b}$ and $2 \mathrm{c}$ but is for samples $2 \mathrm{~d}, 2 \mathrm{e}, 2 \mathrm{f}$ and the unsupported complex. By analogy with $\mathrm{Cu}(\mathrm{acac})_{2}[41,43]$, this is a $\mathrm{C}-\mathrm{H}$ deformation for the $\mathrm{C}-\mathrm{H}$ groups between carbonyls in the triketone. Similar to when $\mathrm{Cu}(\mathrm{acac})_{2}$ is deposited on silica, the appearance of this peak suggests that greater than a monolayer is present.

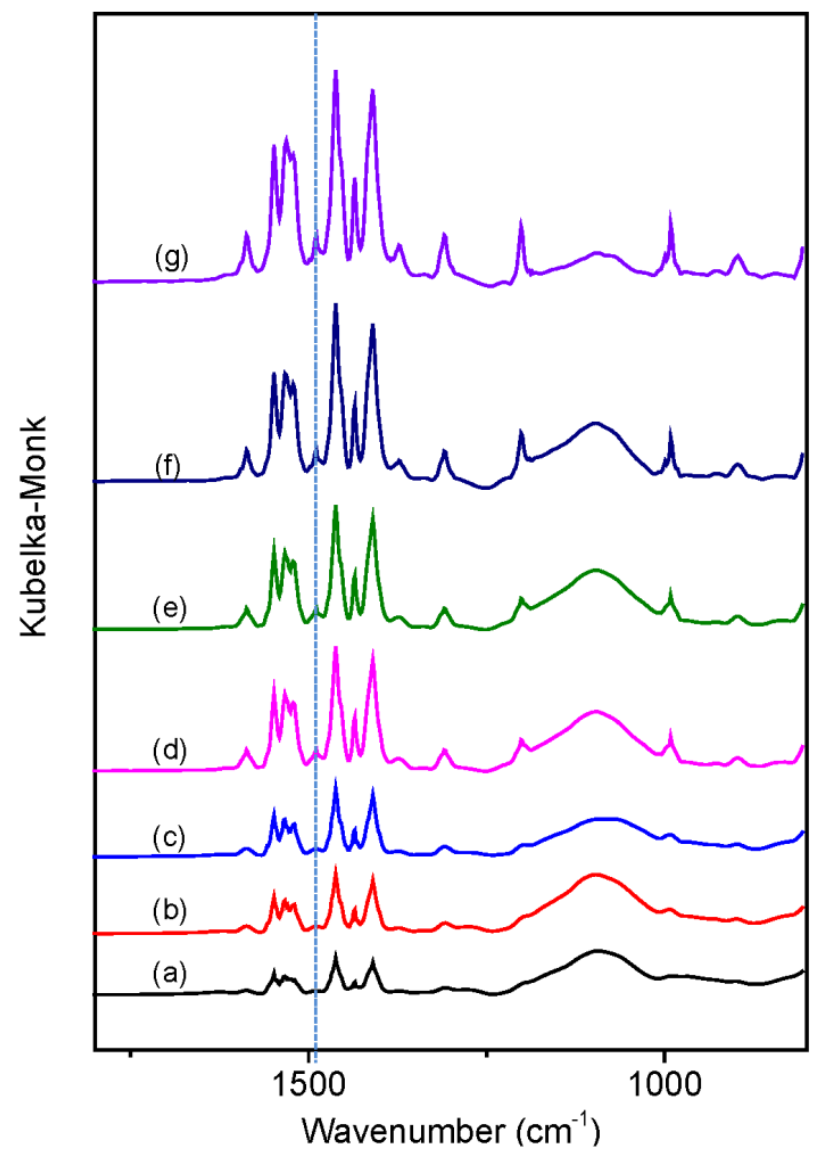

Figure 9. DRIFTS of $\mathrm{Cu}_{2}(\mathrm{dba})_{2}$ /silica at copper loadings of (a) sample $2 \mathrm{a}(\mathrm{b})$ sample $2 \mathrm{~b}(\mathrm{c})$ sample $2 \mathrm{c}(\mathrm{d})$ sample $2 \mathrm{~d}(\mathrm{e})$ sample $2 \mathrm{e}(\mathrm{f})$ sample $2 \mathrm{f}$ and $(\mathrm{g})$ unsupported $\mathrm{Cu}_{2}(\mathrm{dba})_{2}$. The $1488 \mathrm{~cm}^{-1}$ peak is indicated by the dashed vertical line.

Electron paramagnetic resonance spectra were recorded for sample $2 \mathrm{a}$, sample $2 \mathrm{f}$ and $\mathrm{Cu}_{2}(\mathrm{dba})_{2}$ complex as a solid (Figure 10). Sample $2 \mathrm{a}$ has a submonolayer loading and sample $2 \mathrm{f}$ is close to a bilayer system. The unsupported metal complex has a hyperfine structure with four spectral lines in the $g$ (parallel) region and two spectral lines in the $g$ (perpendicular) region. These spectral lines suggest that two copper atoms are not electronically coupled [44]. In the submonolayer sample, spectral lines were significantly broadened due to the low symmetry of 
the molecule when interacting with the surface [45]. In addition, the spectrum of the submonolayer sample has an additional line in the $\mathrm{g}$ parallel region indicating the strong interaction of the metal atoms with the silica support along the $Z$ axis of the metal ion. The multilayer sample has identical spectral lines to that of the unsupported metal complex. The only difference between the metal complex and the multilayer sample is the intensity of peaks. These two samples have EPR spectra characteristic of $\mathrm{Cu}^{2+}$ ions that are magnetically isolated. The single crystal XRD structure of the cis dipyridine adduct has three of the phenyl rings rotated out of the plane of the complex as defined by the two copper ions and the two triketonate ligands [46]. In addition, the copper atoms lie above the plane of the triketonate ligands. As such, these steric factors prevent neighboring metal complexes in the crystal to approaching sufficiently close to allow magnetic coupling of the copper cations. The layers of this complex not in contact with the silica surface will have the same EPR spectrum. The metal complexes in contact with the silica surface are also magnetically isolated as a result of the large triketonate ligands. It is speculated that hydrogen bonding between the silica silanols and electron-rich parts of the metal complex results in a sufficiently close approach of the copper ions to the surface so as to realize coordination between the coppers in the complex and the surface siloxides, thus developing the extra feature observed in the EPR spectrum for the monolayer sample.

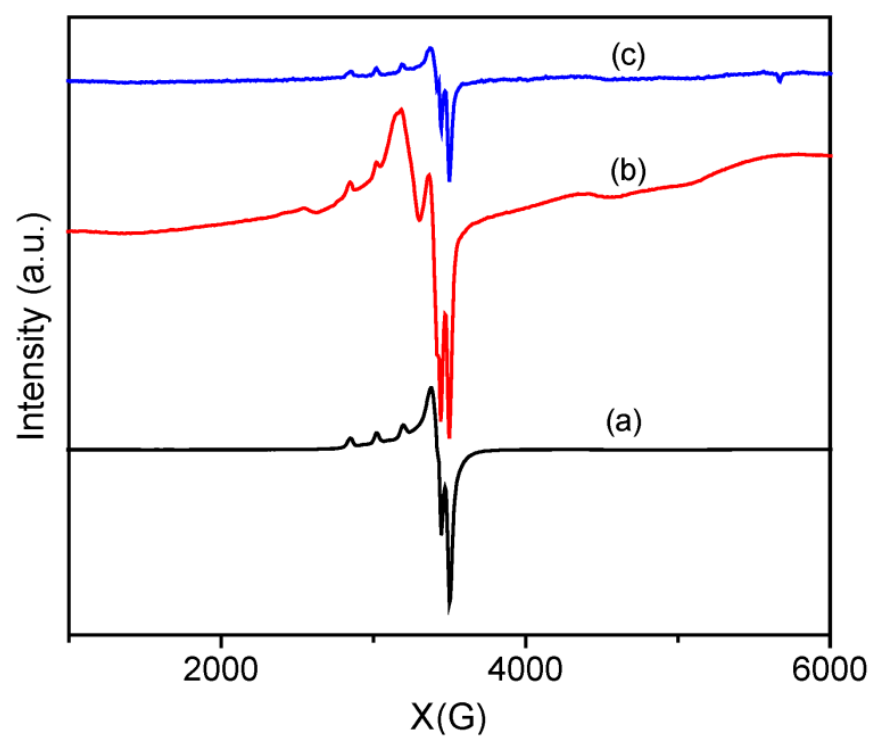

Figure 10. The EPR spectra of (a) unsupported $\mathrm{Cu}_{2}(\mathrm{dba})_{2}(\mathrm{~b})$ sample $2 \mathrm{a}$ and $(\mathrm{c})$ sample $2 \mathrm{f}$

The above results confirm that the adsorption of intact $\mathrm{Cu}_{2}(\mathrm{dba})_{2}$ onto the silica surface was complete in less than a day. A second layer readily deposited on top of the adsorbed monolayer without heat or solvent removal as is required for other systems [47, 48]. Due to metal complex-surface interactions for monolayer formation and subsequent deposition of a second layer, $\mathrm{Cu}_{2}(\mathrm{dba})_{2}$ is an excellent complex for decorating a Cab-O-Sil surface. These studies 
demonstrate that control of complex loading is readily achieved by varying the concentration of complex in the treating solution.

\section{Conclusions}

Two metal complexes, $\mathrm{Cu}_{2}(\mathrm{dba})_{2}$ and $\mathrm{Cu}_{2}(\mathrm{daa})_{2}$, were deposited on $\mathrm{Cab}-\mathrm{O}-\mathrm{Sil}$ by batch impregnations and characterized by UV-vis spectroscopy, elemental analysis, PXRD, TGA and DRIFTS. $\mathrm{Cu}_{2}(\mathrm{daa})_{2}$ loses a ligand upon deposition from THF solution precluding this method for forming copper catalysts. However, $\mathrm{Cu}_{2}(\mathrm{dba})_{2}$ can be supported on Cab-O-Sil as submonolayer, monolayer, and bilayer loading by increasing the concentration of the metal complex in $\mathrm{CH}_{2} \mathrm{Cl}_{2}$ without losing any of ligands. Experimental results suggest that the monolayer formation is complete between 1.36 wt\% and 2.64 wt\% copper loading in agreement with the predicted value of $2.19 \%$ which was obtained from the molecular structure of the dipyridine adduct of $\mathrm{Cu}_{2}(\mathrm{dba})_{2}$. In this structure, the two pyridine ligands are on the same face of the equatorial plane which is unprecedented for dipyridine adducts of dicopper bis triketonates. EPR spectroscopy clearly suggests that the copper centers are in different environments when comparing a submonolayer sample with one having a bilayer deposited.

\section{Acknowledgements}

This manuscript is based upon work performed through the Sustainable Energy Research Center at Mississippi State University and was supported by the Department of Energy under Award Number DE-FG3606G086025.

Special acknowledgement to Dr. W. P. Henry, an author and principal investigator, for his lifetime dedication to inorganic chemistry. Dr. Henry suddenly died of lung cancer (February, 2014).

Disclaimer: This report was prepared as an account of work sponsored by an agency of the United States Government. Neither the United States Government nor any agency thereof, nor any of their employees, makes any warranty, express or implied, or assumes any legal liability or responsibility for the accuracy, completeness, or usefulness of any information, apparatus, product, or process disclosed, or represents that its use would not infringe privately owned rights. Reference herein to any specific commercial product, process, or service by trade name, trademark, manufacturer, or otherwise does not necessarily constitute or imply its endorsement, recommendation, or favoring by the United States Government or any agency thereof. The views and opinions of authors expressed herein do not necessarily state or reflect those of the United States Government or any agency thereof.

\section{References}

[1] N.L. Okamoto, B.W. Reed, S. Mehraeen, A. Kulkarni, D.G. Morgan, B.C. Gates, N.D. Browning, J. Phys. Chem. C, 112 (2008) 1759-1763.

[2] A. Uzun, V. Ortalan, Y. Hao, N.D. Browning, B.C. Gates, ACS Nano, 3 (2009) 3691-3695. 
[3] G. de Ruiter, M.E. van der Boom, Acc. Chem. Res., 44 (2011) 563-573.

[4] M. Fox, J. Whitesell, D. Magde, L.-Y. Zhu, Molecules, 14 (2009) 3851-3867.

[5] M.G. White, Catal. Today, 18 (1993) 73-109.

[6] D.C. Bailey, S.H. Langer, Chem. Rev., 81 (1981) 109-148.

[7] C.W. Jones, M.W. McKittrick, J.V. Nguyen, K. Yu, Top. Catal., 34 (2005) 67-76.

[8] S.L. Wegener, T.J. Marks, P.C. Stair, Acc. Chem. Res., 45 (2012) 206-214.

[9] A.Y. Khodakov, W. Chu, P. Fongarland, Chem. Rev., 107 (2007) 1692-1744.

[10] J.C. Fierro-Gonzalez, B.C. Gates, Chem. Soc. Rev., 37 (2008) 2127-2134.

[11] J.-M. Basset, F. Lefebvre, C. Santini, Coord. Chem. Rev., 178-180 (1998) 1703-1723.

[12] J.C. Fierro-Gonzalez, S. Kuba, Y. Hao, B.C. Gates, J. Phys. Chem. B, 110 (2006) 13326-13351.

[13] H.N. Choksi, J.A. Bertrand, M.G. White, J. Catal., 164 (1996) 484-489.

[14] C.J. Papile, H. Knozinger, B.C. Gates, Langmuir, 16 (2000) 5661-5664.

[15] V. Aguilar-Guerrero, B.C. Gates, Catal. Lett., 139 (2009) 108-120.

[16] S. Khabuanchalad, J. Wittayakun, R.J. Lobo-Lapidus, S. Stoll, R.D. Britt, B.C. Gates, J. Phys. Chem. C, 114 (2010) 17212-17221.

[17] D. Bruce, J.A. Bertrand, M.G. White, AIChE J., 39 (1993) 1966-1975.

[18] F.A. Cotton, G. Wilkinson, C.A. Murillo, M. Bochmann, Advanced Inorganic Chemistry, 6th ed., Wiley, New York, NY, 1999.

[19] M.D. Glick, R.L. Lintvedt, Prog. Inorg. Chem., 21 (1976) 233-260.

[20] D.J. Bray, J.K. Clegg, L.R. Lindoy, D. Schilter, Adv. Inorg. Chem., 59 (2007) 1-37.

[21] S. Kawaguchi, Coord. Chem. Rev., 70 (1986) 51-84.

[22] F. Sagara, H. Kobayashi, K. Ueno, Bull. Chem. Soc. Jpn., 45 (1972) 794-799.

[23] F. Sagara, H. Kobayashi, K. Ueno, Bull. Chem. Soc. Jpn., 41 (1968) 266.

[24] D.P. Murtha, R.L. Lintvedt, Inorg. Chem., 9 (1970) 1532-1535.

[25] R.L. Lintvedt, B.A. Schoenfelner, K.A. Rupp, Inorg. Chem., 25 (1986) 2704-2707.

[26] in, Bruker, Inc., Madison, WI, 2009.

[27] G.M. Sheldrick, Acta Crystallogr., Sect. A, 64 (2008) 112-122.

[28] J.R. Bethell, P. Maitland, J. Chem. Soc., (1962) 3751-3758.

[29] M.L. Miles, T.M. Harris, C.R. Hauser, J. Org. Chem., 30 (1965) 1007-1011.

[30] J. Overgaard, M.-A. Chevallier, B.B. Iverson, Acta Crystallogr., Sect. E, 61 (2005) m922-m924.

[31] R.L. Frost, Y. Xi, B.J. Wood, Thermochim. Acta, 545 (2012) 157-162.

[32] I.V. Babich, L.A. Davydenko, L.F. Sharanda, Y.V. Plyuto, M. Makkee, J.A. Moulijn, Thermochim. Acta, 456 (2007) 145-151.

[33] C.M. Parler, J.A. Ritter, M.D. Amiridis, J. Non-Cryst. Solids, 279 (2001) 119-125.

[34] V.I. Ovcharenko, S.V. Fokin, G.V. Romanenko, A.S. Bogomyakov, D.S. Yachevskii, D.L. Chizhov, V.N. Charushin, O.N. Chupakhin, Russ. Chem. Bull., 59 (2010) 1162-1174.

[35] V.I. Ovcharenko, S.V. Fokin, G.V. Romanenko, V.N. Ikorskii, R.Z. Sagdeev, D.S. Yachevskii, D.L. Chizhov, V.N. Charushin, Russ. Chem. Bull., 55 (2006) 1904-1908.

[36] F. Li, J.K. Clegg, P. Jensen, K. Fisher, L.F. Lindoy, G.V. Meehan, B. Moubaraki, K.S. Murray, Angew. Chem., Int. Ed., 4 (2009) 7059-7063.

[37] A.B. Blake, L.R. Fraser, J. Chem. Soc., Dalton Trans., (1974) 2554-2558.

[38] R.L. Lintvedt, M.D. Glick, B.K. Tomlonovic, D.P. Gavel, J.M. Kuszaj, Inorg. Chem., 15 (1976) 16331645.

[39] M.J. Heeg, J.L. Mack, M.D. Glick, R.L. Lintvedt, Inorg. Chem., 20 (1981) 833-839.

[40] R.L. Lintvedt, J.K. Zehetmair, Inorg. Chem., 29 (1990) 2204-2209.

[41] J.C. Kenvin, M.G. White, M.B. Mitchell, Langmuir, 7 (1991) 1198-1205.

[42] R.K. Beckler, M.G. White, J. Catal., 102 (1986) 252-256.

[43] M.B. Mitchell, V.R. Chakravarthy, M.G. White, Langmuir, 10 (1994) 4523-4529. 
[44] A.H. Maki, B.R. McGarvey, J. Chem. Phys., 29 (1958) 31-34.

[45] K. Dyrek, M. Che, Chem. Rev., 97 (1997) 305-332.

[46] S.A. Ranaweera, M.G. White, W.P. Henry, Unpublished results.

[47] M.K. Niemela, A.O.I. Krause, T. Vaara, J.J. Kiviaho, M.K.O. Reinikainen, Appl. Catal., A, 147 (1996) 325-345.

[48] G.C. Bond, J.P. Zurita, S. Flamerz, P.J. Gellings, H. Bosch, J.G. van Ommen, B.J. Kip, Appl. Catal., 22 (1986) 361-378. 